\title{
TECHNOLOGY AS A DRIVER FOR ECONOMIC DEVELOPMENT IN SOUTH AFRICA
}

\author{
Nicholas Piquito \\ Faculty of Engineering, Rand Afrikaans University \\ Leon Pretorius \\ Faculty of Engineering, Rand Afrikaans University
}

\begin{abstract}
For some time now it has been suggested that technology, in its many forms, is to a large extent responsible for enhancing and driving the process of economic development. The question therefore arises as to whether it is possible to establish a correlation between the level of technological expertise of a nation and its economic development. On the strength of the research results contained in this article, there does appear to be a definite correlation between technology and economic development. Having established the validity of this relationship, the question of whether South Africa is positioned to take advantage of such knowledge is investigated. It is found that economic success in South Africa is to a large degree dependent on the ability of the government and other relevant bodies to establish and sustain a comprehensive, coherent and practical program of technologically driven economic development.
\end{abstract}

\section{OPSOMMING}

Dit word reeds 'n geruime tyd voorgestel dat tegnologie in sy verskeie vorms grootliks verantwoordelik is vir die uitbou en dryfkrag in die ekonomiese ontwikkelingsproses. 'n Vraag wat dus ontstaan is of dit moontlik is om 'n korrelasie te vind tussen die tegnologiese kundigheid van 'n nasie en sy ekonomiese ontwikkeling. Die navorsingsresultate vervat in hierdie artikel toon 'n besliste korrelasie tussen tegnologie en ekonomiese ontwikkeling. Met die bestaan van so ' $n$ verwantskap bevestig is die vraag of Suid-Afrika geposisioneer is om voordeel te trek uit sodanige kennis. Dit word bevind dat die ekonomiese sukses, in SuidAfrika grootliks afhanklik is van die vermoë van die regering en ander relevante instansies om 'n omvattende, koherente en praktiese program van tegnologies gedrewe ekonomiese ontwikkeling daar te stel en te onderhou. 


\section{Introduction}

There are many ways by which it is possible to distinguish between the quality of life in the different countries of the world. One method is to measure the level of economic development within each country. There is a school of thought that technology, or more specifically, the level of technology within a nation coupled with national technology policies, has a significant effect on national, and indeed regional, economic development. It is therefore worthwhile to investigate the concept of technologically driven economic development, but with a distinct focus on the South African context. This is the aim of this article.

\section{Defining Technology}

The definition of technology is a somewhat 'soft' concept in that there appears to be no definitive definition. While many authors reference certain concepts in the definition of technology, each tends to approach the subject from a unique viewpoint [1]. Lanigan [2] defines technology as follows:

Technology is any organised body of knowledge which is applied in a field of human endeavor, such as industry.

According to Lanigan's definition, all of the different fields of engineering are distinct technologies in their own right. Note also the emphasis on the fact that any organised body of knowledge may be considered to be a technology. In general, the word technology is taken to mean a science-based technology, such as engineering [2]. However, fields of human endeavor such as management, design, marketing and accountancy exemplify other organised bodies of knowledge which are applied in industry. Using the definition above, these bodies of knowledge thus also constitute a technology. The difference between these technologies and 'engineering' technologies is that the former is not based on physical science. They thus have no recourse to some of the well understood laws of nature. This leads to the well accepted terminological contradiction of the phrase 'management science'.

This article is primarily concerned with science-based technologies such as those found in engineering. This is not to say that science-based technologies are superior to, or of greater importance, than other forms of technology. It is simply necessary to narrow the scope of focus of this article in order to be able to successfully research the subject at hand. The importance of non-science-based technologies cannot be ignored.

\section{The Importance of Technology}

One way in which technology can help to improve the competitive status between businesses is through product differentiation [4]. Enabling businesses to compete with one another is one of the cornerstones of technological advancement, because in this way better products are produced which use the limited resources of man more effectively and efficiently, and satisfy the unlimited needs of man more effectively. In this way the advancement of man progresses at a rate faster than that which would result were technology as a driving force not present. From a national point of view, the more competitive a country's products are, the more that country is able to influence world markets in terms of, amongst others, technological leadership. Technological innovation may help to distinguish a product in three ways [2]:

1. By providing distinctive and attractive product functions, which leads to greater product sales; 
2. By providing distinctive efficiency in performing those functions offered by the product, which in turn leads to greater product sales; and

3. By reducing the cost of manufacturing the product, which allows the product to be distinguished from its competitors in economic terms. This allows a greater unit profit (or lower unit price which leads to greater sales).

Technology can therefore be seen to offer both opportunities and threats. Technology, and its rate of change, provides opportunities to those businesses (and on a larger scale, those countries) which use it wisely.

Conversely, technology poses threats to the survival and prosperity of those businesses (and yet again those countries) which fail to match the successful technological innovation of their competitors. Technology must therefore be thought of as a strategic factor, since the formulation of strategic technological objectives, and of the best strategies for achieving them, is an important part of any long-term plan. One can therefore refer to the concept of strategic technological planning as an invaluable part of any long-term economic plans.

\section{The Effects of Technological Change}

Sunter [5] provides many examples of the effect of technology on man and his environment. $\mathrm{He}$ describes four 'rules of the game' which a nation must adhere to if they wish to obtain 'the high road' (become a successful nation). The 'rules of the game' as described by Sunter are categories which are likely to continue to be of importance in the future, irrespective of what the future may be. This correlates with the conclusions reached by the mathematical chaos theory, which states that although it is impossible to determine the exact course of a chaotic system (such as weather systems), the constraints on its behaviour may be determined with a certain degree of accuracy. The four 'rules of the game' as listed by Sunter are:

- Population

- Technology

- Social values

- "Winning Nation" and the "Winning Company".

It is apparent that technology, and the effects thereof, are regarded by Sunter as being inevitable, irrespective of the future direction of mankind.

\section{The Concept of Technological Waves and Economic Upswings}

Since 1870 various 'technological waves' have been identified [5]. Such technological waves represent a breakthrough technology, the effects of which were enormous and had a great impact on man. The interesting thing about these so called technological waves is that they have always been followed by economic upswings. These economic upswings are known as Kondratieff waves, so named in honour of the Russian who first drew attention to these long-term cycles. The technological wave in which we currently find ourselves is that of microelectronics and communications. This 'wave' has been in existence for some time now, but, according to Sunter, we are nowhere near the peak yet. It is also predicted that the next wave of technology will be biotechnology and its associated subsidiaries. Concepts such as DNA modification and the use of genetic engineering in practical terms will come to the fore.

\section{The Technological Development Cycle}

In the industrial societies where most technical development takes place, technological and economic developments form an interconnected and self-reinforcing dynamic cycle. 
Typically, as incomes rise, so there is a corresponding rise in wages, making existing forms of technology uneconomic when compared with labour-saving innovations. Greater scientific and technical knowledge combined with greater investment expenditure tend to be associated with rising labour productivity, leading to a further rise in income and a further incentive for innovation.

\section{Economic Development and Technology}

With the information previously presented it is now appropriate to investigate the link between technology and economic development. In order to do this, the choice has been made to compare technology and science related characteristics and indices of various countries with high levels of economic development. The aim is thus to illustrate that, in the absence of additional information and more complex techniques, economically developed countries tend to exhibit technology and science related indices which, when grouped together, correlate well with their levels of economic development.

\section{Scientific Research}

One of the core determinants for the ability of a country to develop and increase its technological capacity is the type and amount of scientific research which is conducted in that country. Naturally, technology does not create itself. Rather, it is a direct outcome of the choices and decisions of people and organizations. The ability of a country to conduct research depends, naturally enough, on the availability of suitable scientific personnel such as scientists and engineers. There is no doubt that the highly developed nations place a greater emphasis on research, made possible by the high ratio's of scientists and engineers in those countries [7]. Table 1 illustrates this point.

\section{Table 1 Scientists and Engineers, 1985, Selected Countries}

\begin{tabular}{|c|c|c|c|}
\hline & \multirow[b]{2}{*}{$\begin{array}{c}\text { Number of scientists and engineers } \\
\text { (thousands) }\end{array}$} & \multicolumn{2}{|c|}{ Scientists and engineers } \\
\hline & & $\begin{array}{l}\text { Per million } \\
\text { population }\end{array}$ & $\begin{array}{c}\text { Engaged in R\&D } \\
(1980) \text { per million } \\
\text { population }\end{array}$ \\
\hline Africa & 1623 & 3451 & 91 \\
\hline Asia & 32670 & 11686 & 272 \\
\hline $\begin{array}{l}\text { Latin } \\
\text { America and } \\
\text { the } \\
\text { Caribbean }\end{array}$ & 4746 & 11759 & 252 \\
\hline Europe & 37369 & 48600 & 1732 \\
\hline $\begin{array}{l}\text { North } \\
\text { America }\end{array}$ & 33247 & 126200 & 2678 \\
\hline Oceania & 1105 & 48213 & 1483 \\
\hline $\begin{array}{l}\text { Developed } \\
\text { countries }\end{array}$ & 81247 & 70452 & 2984 \\
\hline $\begin{array}{l}\text { Developing } \\
\text { countries }\end{array}$ & 29513 & 8263 & 127 \\
\hline
\end{tabular}

Source: Malecki, Edward J. "Technology and Economic Development" John Wiley \& Sons Inc. 1991 [7] 
It is immediately obvious that there is a massive difference in the number of scientists and engineers in developed (in other words economically developed) and developing countries. This is evident if we compare the figures for scientists and engineers per million population for developed countries $(70,452)$ and developing countries $(8,263)$, which equates to a factor of 8.5. However, if we look at the figures for scientists and engineers involved in research and development work, this factor moves up to 23.5. The lack of emphasis on research and development in developing countries has a negative effect on the technological capability of these countries [7]. If one looks at where the majority of scientific research is conducted on a global basis, the correlation between the numbers of scientists and engineers and the type and amount of research becomes clear.

It is interesting to note that even amongst highly developed nations, there is not necessarily uniformity in the way in which scientists and engineers are used in research. This is well illustrated by the differences between a Japanese company and a Western company. A modern Japanese company has more engineers in applied research, product development and design, production systems and process improvements than an equivalent Western company. This is counterbalanced by having fewer scientists and engineers in basic research [5]. Japanese companies thus introduce a lot more effort into the front-end design of a product as well as ensuring that the processes to produce the product are simplified in order to cut lead times and to minimise labour usage. The result of this is that the added value per employee in modern Japanese companies is traditionally exceptionally high. For example, the revenue per employee in an average South African gold mine is in the region of $\$ 16,000$. Compare this with the average revenue per employee of Nintendo which is $\$ 4.9$ million [5]. This makes Japanese companies extremely cost effective, with a highly skilled and efficient labour force.

The differences between Japan and the West in this regard is shown in Figure 1. Notice how Japanese companies tend to have smaller numbers of better trained personnel involved in daily work functions, while emphasis is given to research, production development, and design.

\section{RELATIVE SOURCES OF COMPETITIVE ADVANTAGE}

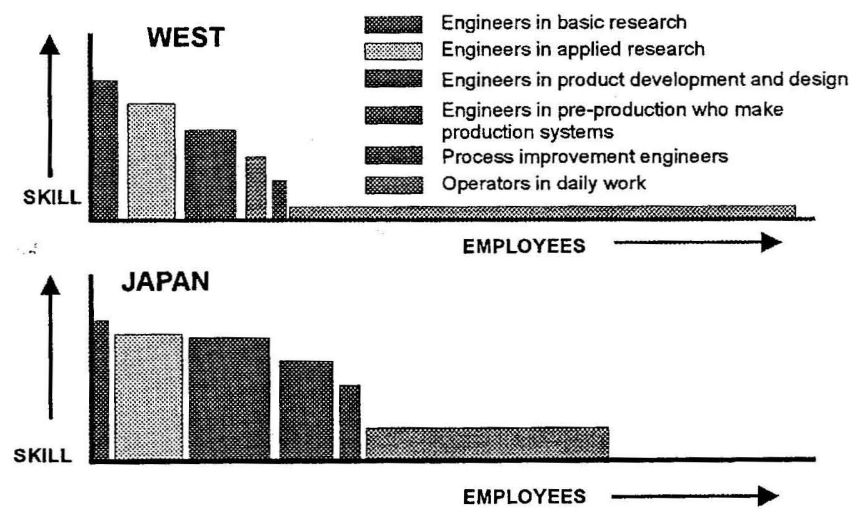

Figure 1 Relative Sources of Competitive Advantage 
In order to investigate the link between engineers and scientists (and hence technological capability) and economic development, a recent article by Boyd [8] provides some useful insights into the problems facing South Africa. In this article, the following points are highlighted:

- The shortage of technically trained human resources in South Africa is fast becoming a major impediment towards achievement of economic growth

- The state of science and technology is an important indicator of global competitiveness and forms the basis for sustainable economic development. By international standards South Africa ranks very poorly.

- South Africa produces 15 times fewer graduates per million of the total population than Japan, 8 times fewer than the US, and 6 times fewer than Australia.

- South African universities' intake of engineering students has been declining since 1990. This, together with the fact that the total enrollment at South African universities has increased by 80 percent since 1985, points to an unhealthy imbalance between arts and humanities on the one hand and science and engineering on the other.

- In Japan, where one third of university students are registered for engineering courses, the ministry of education has estimated that the country still has a national shortage of engineers, and is devising plans to increase the intake of students into the engineering streams by 10 percent per year.

Williams [9] refers to applied research and development as "simply a form of investment, and in many cases a form of investment which cannot yield an economic return unless it is followed by a very much larger investment in plant and equipment and marketing". He points out further that it is possible to hinder economic development by employing too high a proportion of scientists and engineers in research and development, since scarce scientific and engineering manpower may be used in a variety of employments. In particular the emphasis of Williams' study is the implications of the large research gap between Western European countries and the United States.

Williams, however, indicates that scientific research is not the only determinant of technological, and thus by implication, economic development. In his words: "Research and development is important for growth but the idea that a country's growth depends on its own R\&D overlooks the great importance of the international movement of ideas, of machines which embody the results of $R \& D$, and of capital transfers to make possible the use in various countries of technological and managerial inventions made elsewhere." It is thus apparent that the appropriate level of research and development, with respect to economic development, will vary from country to country with the level of technology, the supply of scientific manpower, the industry $\mathrm{mix}$ and the cost of importing new technological knowledge.

Williams [10], illustrates how the growth of a country's GDP may be affected by three parameters, namely. (a) an increase in the labour force, (b) an increase in capital stock or conversely, capital expenditure, and (c) technical progress. His results are shown in Table 2.

This table illustrates two important points:

1. Technological progress is not the sole contributor to growth in GDP, as is to be expected, and

2. Notwithstanding the point made above, technological progress appears to play a major role in growth in GDP. 


\begin{tabular}{|c|c|c|c|c|c|c|}
\hline \multirow{2}{*}{$\begin{array}{l}\text { Country } \\
1949-54\end{array}$} & \multicolumn{3}{|c|}{$\%$ Annual rates of growth of } & \multicolumn{3}{|c|}{$\%$ Estimated contribution in growth of } \\
\hline & Labour & Capital & GDP & Labour & Capital & $\begin{array}{l}\text { 'Technical } \\
\text { progress' }\end{array}$ \\
\hline Belgium & 0.6 & 2.4 & 3.6 & 0.4 & 0.7 & 2.5 \\
\hline Canada & 2.1 & 7.1 & 4.3 & 1.5 & 2.1 & 0.7 \\
\hline Netherlands & 1.4 & 4.0 & 4.9 & 1.0 & 1.2 & 2.7 \\
\hline Norway & 0.2 & 4.4 & 3.7 & 0.1 & 1.3 & 2.3 \\
\hline Sweden & 0.5 & 2.0 & 3.4 & 0.3 & 0.6 & 2.5 \\
\hline UK & 0.6 & 3.1 & 2.5 & 0.4 & 0.9 & 1.2 \\
\hline France & 0.1 & 2.9 & 4.8 & 0.1 & 0.9 & 3.8 \\
\hline Italy & 1.5 & 3.0 & 6.4 & 1.1 & 0.9 & 4.4 \\
\hline
\end{tabular}

Source: Williams B. R. "Investment and Technology in Growth" A paper read to the Manchester Statistical Society, January 1964 [10]

Given the evidence presented thus far, it would appear as if technology, and its use and development, has a direct and discernible effect on, amongst others, the rate of GDP growth within a country, and hence by definition the rate of economic growth and development. While the science of correlating economic growth to technological 'strength' is not an exact one, the amount of evidence which suggests such a correlation is too strong to be ignored. While there has been research carried out which points to a neutral relationship between these two elements under specific conditions, such as that proposed by Williams [11], such evidence is in the minority. As is acknowledged by many authors [12], [3], [7], the multitude of factors which can affect such a correlation may lead to differing conclusions by different authors.

\section{Ogburn's Theory of Cultural Change}

Ogburn [13] is regarded as one of the leading proponents of technologically driven economic development, with particular emphasis on the effect of technology not only on economic development, but also on social development. During numerous research studies Ogburn was able to show time and again that technology was one of the prime causal factors driving the economic development of a nation [14]. According to Ogburn, technological development and new discoveries in applied science were found to be by far the most important factors bringing about the increase in the standard of living in the United States of America during the period 1930 - 1950. This is attributed to the fact that in the first half of the century three important factors of technological development increased at rates commensurate with or superior to the rise in the standard of living, namely:

- The annual number of patents granted,

- The value of reproducible equipment in industry and on farms, and

- The supply of mechanical energy.

Similarly, Nimkoff and Ogburn [15] find that technology and the use thereof is of prime importance in explaining the increase in the average per capita production in the United States during the middle of the century. Just as important (and perhaps even more so in the 
view of the authors), it is found that much of the education that is responsible for increased productivity is technological rather than, say, that found in a 'liberal arts college'. This is particularly important in the South African context given the dramatic shortage of skilled people trained in the hard sciences (more on this later). Consequently, Nimkoff and Ogburn attribute the increase in family income in the United States of America primarily to technological and scientific developments.

Cunningham [16] studied the effects of education and technology on the economic development of certain countries, with an emphasis on education as the single variable. This was a modification of Ogburn's theorem in that Ogburn emphasised the major influence played by technology in cultural change and economic development. Nevertheless, Cunningham's findings, using a factor analysis technique, was that "education and technology are both necessary though not sufficient conditions for economic development, and that education - technology - economic development may represent a causal sequence."

In particular, the following two conclusions are emphasised by Cunningham:

- There is a strong relationship between technology and economic development which is consistent with previous studies associated with these variables, and

- There is a positive correlation between education and economic development.

In his study, Cunningham, using a different approach to that adopted by Ogburn, reaches a similar conclusion in that technology (and education in this case) appears to have a direct influence on the level of economic development of a country.

\section{Technological Factors and Influences Driving Economic Development}

The release of the 1997 Global Competitiveness Report by the World Economic Forum [17] provides insight into some of the factors which are considered to be of importance in establishing a country as a global competitor. In this report, South Africa ranked $44^{\text {th }}$ amongst 53 countries rated, against the previous year's results of $43^{\text {rd }}$ amongst 49 nations [18]. In the report, eight factors were singled out as being a determinant of global competitiveness (by necessity these factors represent only a limited number in the possible range - see the World Competitiveness Yearbook for additional examples). These factors are: (1) the openness of an economy to international trade and finance, (2) government's budget and regulatory policies, (3) development of financial markets, (4) quality of infrastructure, (5) quality of technology, (6) quality of business management, (7) labour market flexibility, and (8) quality of judicial and political institutions.

Of these eight factors, four are associated with the level of technology within a country (financial markets, infrastructure, quality of technology and business management), either directly or indirectly. It is therefore apparent that the level of global competitiveness of a country may be greatly enhanced by the level of technology within that country. It is interesting to note that South Africa fared better in the more technological aspects of the report than it did in other aspects such as labour and management. South Africa's rankings were as follows: infrastructure $\left(26^{\text {th }}\right)$, finance $\left(32^{\text {nd }}\right)$ and technology $\left(34^{\text {th }}\right)$.

The forum's rankings showed that the world's most competitive economies were Singapore and Hong Kong, while the least attractive were Russia and the Ukraine.

Organisations such as The International Association for Science and Technology in Development (IASTED) place great emphasis on education as a factor in meeting the needs of a country's economic development [19]. Emphasis is thus placed on technical and 
technological education as a prerequisite to economic development. In addition, non-profit organisations such as the State Science \& Technology Institute (SSTI) in the United States of America continually provide research and publications on the ways in which technology can best be used in the promotion of economic growth and development [20]. The United States in particular is very prevalent in that they have a large number of organisations who specialise in the use of technology in economic development. For example, the Microelectronics Center of North Carolina (MCNC) is a private, nonprofit corporation located in Research Triangle Park, North Carolina. MCNC provides advanced resources in electronic and information technologies to support education and industry and to enhance technology-based economic development in North Carolina [21].

\section{South Africa's White Paper on Science and Technology: A Future Perspective}

Perhaps one of the best indicators of government policy on the question of science and technology and the role which these elements have to play in the economy can be found in the White Paper on Science and Technology, entitled Preparing for the $21^{\text {st }}$ Century [6].

It is heartening to find that the government does appear to realise the importance of science and technology on the economic well being of a nation. This is highlighted on numerous occasions within the Paper. For example, it is stated that: "Science, engineering and technology (SET) have time and again demonstrated their capacity to generate new and better ways of doing things, thereby contributing to higher standards of living and a better quality of life." In addition, the point is stressed that "Studies of international indicators show that science, engineering and technology (SET) are absolutely vital components of economic and social progress." One can therefore assume that the government, and various policymakers, are aware of the tremendous role which science and technology may play in South Africa's economic development.

However, with all the best will in the world, it is going to take action, and not words, to place South Africa on the path to successful technologically driven economic development. The predicament in which South Africa currently finds itself can be illustrated by the following facts:

- Most industrialised countries usually spend of the order of 2 percent of GDP on research and development, while the trend amongst newly industrialised countries is to increase their spending on research and development.

- Research and development is generally regarded as the principle mechanism for generating innovation in a country, and without research and development a nation becomes increasingly uncompetitive (a measure of a nation's competitiveness, for example, is the number of patents held worldwide by citizens of that country).

- South Africa's current level of spending on research and development is 0.75 percent of GDP, which does not compare favourably with other industrialised and newly indûstrialised countries (Australia 1.34 percent, Canada 1.5 percent, Japan 2.87 percent, USA 2.75 percent).

- The tendency over the past number of years has been for South Africa's spending on research and development to decrease, from a maximum of 1.04 percent in 1987. This is in sharp contrast to countries with a successful track record in industrial development.

It is therefore apparent that as the situation currently stands, South Africa is in danger of suffering a major decline in science and technology related elements. Given that it has been established that science and technology can play a major role in economic development, it thus follows that one may expect the economic development of South Africa to be severely impacted unless steps are taken to remedy the situation. 
All is not lost however. South Africa is fortunate in that it has well developed areas of technological and scientific expertise which produces excellent research. For example, our financial services sector is on par with the best in the world. We are acknowledged leaders in fields such as corrective medicine and synthetic fuel technology, and South African deep mining expertise is sought after world-wide. However, even in such areas where we have a relative competitive advantage over other countries, there is a worrying lack of human resources development. The result of this is deep systematic weaknesses, particularly in the areas of management and technical skills.

It is the intention of the government, as laid down in the White Paper, to focus on the ways in which South African levels of science and technology can be improved in order to allow this country to compete competitively with the rest of the world. If this is not done, then judging by the evidence presented thus far, South Africa will find it hard, if not impossible, to increase its level of economic development.

\section{Science and Technology in South Africa: The Present Position}

Nabarro [22] in his presentation of the George Campbell Lecture ${ }^{\mathbf{1}}$, makes many references to the current state of technology and science within South Africa. Amongst many others, he highlights the following points:

- It appears that South Africa has well-devised and ably manned official structures for the coordination of research and development (such as the Council for Scientific and Industrial Research); and

- It is expected that the list of industries in which South Africa is a leader (such as deep mining) will be considerably shortened in the coming years.

In other words, while South Africa has the structures necessary for the coordination of scientific research, the fact that South Africa is expected to be less competitive internationally in terms of leading expertise indicates that these structures are not being properly used, to the detriment of South Africa. Pouris [23] of the Foundation for Research and Development (FRD) has attempted to make various quantitative assessments of the state of various scientific and technological disciplines in South Africa. The results are not particularly encouraging. Using the index of the number of publications produced by a country in a particular field per year, South Africa's best ranking among the nations of the world was $14^{\text {th }}$ place in the Earth and Space Sciences in 1973, falling to $21^{\text {st }}$ in 1984 . The worst rankings were achieved in Mathematics and Physics in 1984, both ranking $33^{\text {rd }}$.

Reynhardt [24] argued that a better index would be the publication of research articles per million of population. In this case, his figures for 1988 put South Africa in $26^{\text {th }}$ place, just ahead of Spain and Yugoslavia, and just behind Greece, Bulgaria and Chile. Pouris [23] goes on further to investigate not only the quantity, but also the quality, of South African scientific publications, and finds that the relevant citation index for each of eight filed papers surveyed during the years 1973-1984 was around three quarters. In other words, statistically, each paper by a South African author was quoted only about three-quarters as often as the average paper in its field. Such figures are not encouraging, and possibly provide a clue to the remedy needed.

\footnotetext{
${ }^{1}$ The George Campbell Lecture was established jointly by the University of Natal and the Royal Society of South Africa. The Seventh George Campbell Lecture was delivered in Pietermaritzburg on Monday, 30 October 1989 by Frank R. N. Nabarro, Professor Emeritus, University of the Witwatersrand, Johannesburg.
} 
In South Africa's White Paper on Science and Technology [6], five possible strategies with regards to science, engineering and technology are proposed. The role of these strategies is to harness the power of science, engineering and technology to ensure that South Africa is able to find an acceptable quality of life for all its citizens. The proposals are that science, engineering and technology needs to be harnessed so as to:

- Increase the competitiveness of the South African economy, particularly on a global scale as the world enters a new age of internationalisation and globalisation;

- Devise more efficient ways of harnessing and sustaining South Africa's natural resources, in particular water which is perhaps the scarcest and most important resource;

- Provide a suitable infrastructure at minimum cost, which is particularly important if South Africa wishes to attract foreign investment;

- Develop and utilise South Africa's human resources to the full; and

- Improve the quality of life.

The proposals as put forward here cannot and will not be satisfied if the power of science, engineering and technology is not used to its full potential.

\section{Establishing a Technological and Scientific Policy Structure}

One of the first requirements of any developing nation which wishes to harness the power of technological advancement is the need for a coherent and structured approach to scientific and technological policy. This is well illustrated by the economic development of East Asian countries over the past decade [25]. This can only be achieved if the appropriate structures are in place, the purpose of which will be to guide the various institutions concerned along the correct path and to make sure that everyone is working towards a common goal. While South Africa does have such structures in place, their effectiveness is often questioned, and it would perhaps be wise to investigate whether it is time for a re-think on the roles and responsibilities of such structures within the scientific and technological environment in South Africa.

Nabarro believes that it is necessary to have an advisory structure with direct access to the government. He goes on further to suggest that South Africa follow the trend in Britain whereby a Chief Scientific Advisor along with a top Advisory Council on Science and Technology have direct access to the head of government. Whether this would have a marked effect on, for example, the level of technological development or the relevant citation index is debatable, but even if they do little good it would seem that they are unlikely to do much harm. Given the limited number of leading scientists and engineers in South Africa it may be desirable to consider a smaller and simpler advisory structure (than that of the United Kingdom), though one which still retains the necessary level of intellectual and political power.

The effect of establishing such a structure will be twofold: (1) It will provide scientists and engineers with a more direct access to government, the result of which will be a greater ability to influence technological and scientific policy, and (2) It will encourage a more structured approach to development which would (theoretically at least) allow for greater cooperation between existing and new institutions within South Africa. 


\section{Regional Cooperation}

Nabarro makes a strong case for regional cooperation between universities, various government levels and private enterprises. Indeed, the United States of America has had numerous successes with the creation of so called 'research triangles' or 'research parks' which facilitate regional cooperation between various elements [22]. Perhaps the most successful of these has been the Research Park which was implemented in the State of North Carolina. This 'research park' is a triangle defined by three universities: Duke University in Durham, the University of North Carolina at Chapel Hill and North Carolina State University at Raleigh. The results of the establishment of this research park have been impressive:

- In the 1950 s the state ranked $45^{\text {th }}$ in the United States in personal income. In 1986 this had improved to $37^{\text {th }}$ position.

- In the four-county region surrounding the triangle, the unemployment rate fell to 3.3 percent in 1986, compared to 5.3 percent for the United States overall.

- The Park itself is the largest centre of its kind in the world, with a work force of 27000 and an annual payroll of more than $\$ 1$ billion. It has more $\mathrm{PhD}$ 's per capita than any comparable area in the USA.

- Its institutions attract annually in excess of $\$ 425$ million in 'university related research funding'.

In addition, many of the worlds largest companies have set up specialised research centres within the triangle, thereby further enhancing the research and development conducted.

While one is not necessarily suggesting that South Africa copy this concept as is, it does illustrate the power of regional cooperation, and the various decision making bodies within South Africa would be well advised to consider this concept in the short to medium term.

However, the concept of regional cooperation, while successful overseas, has yet to be fully embraced by institutions in South Africa. A number of initiatives have been started, but have not yielded the required results. While it is not the intention of the authors to investigate this concept in too much detail, perhaps a separate study on the merits of regional cooperation in South Africa might be a good idea. Nevertheless, this concept has proved to be very effective overseas, when it is managed correctly. It would certainly be worthwhile for the different institutions in South Africa to make a concerted effort at promoting regional cooperation.

\section{Encouraging Education and Training in the Science and Technology Fields}

One of the greatest problems faced by South Africa is the low number of students who choose to be educated or receive training in the 'hard sciences', such as mathematics and engineering. This immediately places South Africa at a disadvantage to the rest of the world where the situation is different. For example, as a career choice in South Africa, engineering ranked seventh or eighth, compared to first world countries where it ranked first [26]. In 1994 435,000 people held degrees in South Africa. A breakdown of the types of degrees held shows that literature and philosophy (including psychology and social sciences) accounted for 28 percent of the degrees held. The next most held degree was commerce (12 percent), followed by natural sciences ( 10 percent), education ( 8 percent), engineering ( 6 percent) and accounting and management (just below 6 percent). And although there was a 24 percent increase in the number of engineering degrees awarded between 1990 and 1994, they constituted between 4 percent and 5 percent of the degrees awarded and therefore shrank as a proportion of the total. Degrees in mathematics increased by 27 percent but accounted for only 2 percent of the total [27]. 
In addition, according to statistics from the Ministry of Labour, only 20 percent (some 3 million people) of South Africa's workforce is skilled or highly skilled, as compared to around 7 million semi-skilled or unskilled workers. The result of this is that South Africa's skills profile compares very poorly with other middle income and industrialised countries, with 3.7 percent of professionals in its workforce as compared to an average of 7.8 percent in middle income countries and 10.5 percent in advanced industrial countries [28].

At a recent National Engineering Awards ceremony, Roy Marcus, chairman of the South African Engineering Association, warned that South Africa's shrinking engineering population was a threat to economic growth [26]. Furthermore, the country's potential as a global competitor was measured in terms of the number of engineers per million of its population. Comparing this statistic for South Africa with countries such as Australia and Japan, it is apparent that South Africa does not produce a comparable per capita number of engineers. This will have serious economic consequences going forward.

It is therefore imperative that the government take strong measures to encourage South Africans to study for a career in the areas of science, mathematics, engineering and technology. If South Africa is to take advantage of the concept of technologically driven economic development, then it is absolutely vital that immediate steps be taken to improve the skills base which will be necessary for such a step. It is apparent that South Africa does not have much choice on the matter. With the advent of globalisation it is necessary, now more than ever, for South Africa to establish a competitive advantage by ensuring the availability, now and in the future, of the necessary technological and scientific skills to encourage economic development on the appropriate scale.

\section{Translating Science Into Effective Technology}

South Africa's White Paper on Science and Technology highlights what is widely believed to be one of the largest failures of existing policy with regards to science and technology as follows:

"Although South African science is relatively strong, it rarely translates into effective technology. Science and technology should therefore be better integrated via multi disciplinary programs without sacrificing the strength of our basic science."

One would therefore suspect that government policy in the future would emphasise the 'usefulness' of scientific research [6]. While the authors have no objection to this, and indeed believe this to be a sound and practical idea, caution must be taken not to introduce the other extreme whereby a vast majority of scientific research is eliminated because of doubts about its 'usefulness'. It is therefore important that a careful balance be found between practical research and theoretical research. Both are necessary if South Africa is to prosper as a winning nation.

\section{Concluding Summary}

The aim of this article was to investigate the concept of technologically driven economic development and to relate this concept to South Africa's future policies with regard to science, engineering and technology. During the course of this article, the following has been accomplished:

- an analysis of the concept of technology was presented,

- the correlation between technology and economic development was investigated, and 
- South Africa's current state of science, engineering and technology as well as future requirements with regard to technologically driven economic development was investigated.

It was found that there is an identifiable link between the level of technological and scientific expertise within a nation and the level of economic development within that nation. The concept of technologically driven economic development is thus a viable one, knowledge of which will prove to be a powerful weapon in the quest for improvement in the quality of life of a nation, and hence by definition, the level of economic development within that nation. The only related question which remains unanswered, but which is recommended for further investigation, is the relative importance of technology amongst the factors which promote economic development. This study has made no attempt to investigate this concept, but has focused on confirming the correlation between technology and economic development. In addition it was found that all of the highly developed (industrially and economically) countries of the world place great emphasis on science and technology as a means of promoting economic development. It is therefore possible to conclude that technology, while not the only factor influencing economic development, plays a great role in promoting and enhancing national, and even regional, economic development.

At present, South Africa's science and technology base is found to consist of both weak and strong points. South African expertise is comparable with the best in the world in certain areas (such as deep mining technology and synthetic fuel technology) [5] but is sadly lacking in others [5], [6]. This is due to a large extent (but not entirely) to the disappointingly low number of professionals in the science and technology related industries. South Africa is often at the bottom of rankings amongst industrialised and semi-industrialised countries with regards to indices such as the number of engineers per capita or the amount spent on research and development per capita. Perhaps even more serious is the current trend towards a reduction in student intake in the 'hard science' fields. This is a trend which South Africa can ill afford.

This study therefore puts forward several recommendations designed to improve South Africa's science and technology base. Such recommendations range from the obvious (encouraging more students to study in the science and technology fields) to the less obvious (the creation of 'research parks' as a means of promoting cooperation amongst different institutions in South Africa). One important underlying theme which can be found throughout this document is the need for the formulation of a comprehensive science, engineering and technology (SET) strategy by the government and other interested bodies to be given maximum priority. It is only through a structured approach, with the involvement of all relevant parties and institutions, that South Africa will be able to increase the level of its science, engineering and technology base so as to be able to compete with the industrialised countries of the world.

With the establishment of a competitive SET infrastructure and a knowledge of the power of technology in influencing the level of economic development of a nation, South Africa does indeed have a tremendous opportunity to take advantage of the concept of technologically driven economic development. 


\section{Bibliography}

[1] Webster A., "Science, Technology and Society" Macmillan Press Limited 1991

[2] Lanigan M., "Engineers in Business: The Principles of Management and Design" Addison-Wesley 1992

[3] Johnson H. G., "Technology and Economic Interdependence" Macmillan Press Limited 1975

[4] Liker J. K., Ettlie J. E., Campbell J. C., "Engineered in Japan" Oxford University Press 1995

[5] Sunter C., "The New Century: Quest for the High Road" Human \& Rousseau (Pty) Ltd/Tafelberg Publishers 1992

[6] Preparing for the $21^{\text {st }}$ Century: White Paper on Science and Technology The Department of Arts, Culture, Science and Technology, South Africa November 1996

[7] Malecki E. J., "Technology and Economic Development" Longman Scientific \& Technical/John Wiley \& Sons, Inc. 1991

[8] Boyd L., "Future economic growth at risk without more engineers" Business Day, 10 June 1997

[9] Williams B. R., "Technology, Investment and Growth" Chapman and Hall Limited 1967 [10] Williams B. R., "Investment and Technology in Growth" A paper read to the Manchester Statistical Society, January 1964

[11] Williams B. R., "Assessing the Economics of Innovation" Science and the City, Hambros Bank and New Scientists, November 1963

[12] Lucas R., "On the Mechanisms of Economic Development" Journal of Monetary Economics, 22, 3-42

[13] Ogburn W. F., "William F. Ogburn on Cultural and Social Change" The University of Chicago Press 1964

[14] Ogburn W. F., "Technology and the Standard of Living" The American Journal of Sociology, LX (May 1955)

[15] Nimkoff M. F., Ogburn W. F., "Technology and the Changing Family" Houghton Mifflin Company 1955

[16] Cunningham D. G., "The Impact of Education and Technology on Economic Development in Selected Countries: A Modification of Ogburn's Theory of Cultural Change" A thesis submitted for the degree of Doctor of International and Intercultural Development Education, Florida State University, 1980

[17] Institute for Management Development World Competitiveness On-Line: The World Competitiveness Scoreboard Extract from the world wide web site of the IMD (www.imd.ch/wcy/factors/overalldata.html)

[18] Steyn G., "World Business Executives Rate SA Third Worst for Organised Crime" Business Day, 21 May 1997

[19] Information obtained from the World Wide Web page of The International Association of Science and Technology for Development (http://www.iasted.com/)

[20] Information obtained from the World Wide Web page of the State Science \& Technology Institute (http://www.ssti.org/index.htm)

[21] Information taken from the World Wide Web site of the Microelectronics Center of North Carolina (http://www.mcnc.org)

[22] Nabarro F. R. N., "The Organization of Science and Technology in South Africa" University of Natal Press 1990

[23] Pouris A., "Assessing Basic Research in South Africa" S A J Science 84 (1988)

[24] Reynhardt E. G., "Universiteitsnavorsing in die Fisiese Wetenskappe in Perspektief" S A J Science 78 (1982)

[25] McRae H., "East Asia Performed Economic 'Miracle' by Catching Up" The Independent, Tuesday 16 September 1997 
[26] Lund T., "30\% of all students who graduate as engineers in SA leave for abroad" The Star, Tuesday 15 April 1997

[27] O' Grady K, "Number of qualified blacks is increasing" Business Day, Thursday, June 121997

[28] "University degree now only a stepping stone to guaranteed employment" The Careers Guide, The Star, Tuesday September 301997 